\title{
繁殖育成豚および繁殖母豚の脚弱に関する実態調査
}

\author{
新井佐知子 ${ }^{1}$ ・堀北哲也 ${ }^{2)}$ - 加島 宏 ${ }^{1)} \cdot$ 古屋 浩 ${ }^{3)} \cdot$ 吉浦尚子 ${ }^{1)} \cdot$ 島村優理 ${ }^{4}$ \\ 1) 千葉県農業共済組合連合会 北部家畜診療所（ T 289-0407 千葉県香取郡山田町仁良字牧野 99-1） \\ 2) 千葉県農業共済組合連合会 西部家畜診療所（ T 260-0001 千葉県千葉市中央区都町 568-1） \\ 3) 千葉県農業共済組合連合会 東部家畜診療所（† 289-1326 千葉県山武郡成東町成東字渡戸 1533） \\ 4) 千葉県農業共済組合連合会中央家畜診療所（～299-0126 千葉県市原市天羽田 736）
}

\section{Investigation of Leg Weakness on Gilts and Sows}

\author{
Sachiko ARAI ${ }^{1)}$, Tetsuya HORIKITA ${ }^{2)}$, Horoshi KASHIMA ${ }^{\text {"), }}$ \\ Hiroshi HURUYA ${ }^{3)}$, Naoko YOSHIURA ${ }^{1)}$, Yuri SHIMAMURA ${ }^{4)}$ \\ Hokubu Veterinary ClinicalCenter, \\ Chiba Prefectural Federation of Agriculture Mutual Aid Association, \\ 1) Hokubu Veterinary Clinic Center, 99-1 Nira-Makino, Yamada-machi, Chiba 289-0407, \\ 2) Seibu Veterinary Clinic Center, 568-1 Miyako-machi, Chuo-ku, Chiba-shi, Chiba 260-0001, \\ 3) Tobu Veterinary Clinic Center, 1533 Naruto-Watarido, Sanbu-gun, Chiba 289-1326, \\ 4) Chuo Veterinary Clinic Center, 736 Amouda, Ichihara-shi, Chiba 299-0126, Japan \\ (Received 25 May, 2004 / Accepted 12 June, 2004)
}

\begin{abstract}
Summary
Conditions of legs, walking, standing, and staying about 94 gilts and 135 sows of 11 farms located in Chiba prefecture were invedtigated during Oct.2002 to March 2003 as survey of legweakness. For gilts, upright of fore legs, upright of hind legs and hind legs turned out were $9.6 \%, 13.8 \%$ and $13.8 \%$ of them, respectively. For sows, weak pastern of fore legs, weak pastern of hind legs and hind legs turned out were $28.1 \%, 46.7 \%$ and $43.0 \%$ of them, respectively. Percentages of middle severe and severe of standing condition were $17.2 \%$ and $3.4 \%$ of sows. For staying condition, $15.0 \%$ of them were unstable. $18.3 \%$ and $41.9 \%$ of gilts showed stiff locomotion and swaying hindquarter, respectivery. Much of low BCS of sows showed arthritis, weak pastern and difficulty to stand. These symptoms observed for sows at all farms and hind legs had more symptoms than fore legs.
\end{abstract}

豚の運動器疾患は全国や千葉県で年間死廃頭数の約 $30 \%$ 占めている ${ }^{9)}$ 。運動器疾患には関節炎, 蹄病など の炎症性疾患と，骨軟骨症などの非炎症性疾患があり， 特に骨軟骨症は起立不能や歩行困難など重症になってか ら発見され淘汰の対象とされる場合が多く, 問題とされ ている ${ }^{1-3)}$ 。近年, 大型で成長が早く, 産肉性の高い系統

連絡先 : 堀北哲也

厂 276-0049 千葉県八千代市緑が丘 2-5-12

Tel : 047-450-6218

Fax : 047-450-6248

E-mail : horikita@olive.ocn.ne.jp
が繁殖母豚として好まれ多く用いられる反面, 成長の早 さに骨や関節の発達が追いつかず, 結果的に運動器疾患 を発現して淘汰される例も多い1。さらに高エネルギー の飭や運動制限が骨軟骨症の発現を早めることも示唆さ れている2,6,9)。また, 骨軟骨症は脚弱の原因のひとつに なっている ${ }^{1,8)}$ 。脚弱は外見上肢蹄が示す異常症状で, 外 見上診断しにくい骨軟骨症の診断の目安となる可能性が あると考え，今回はその実態を知る目的で繁殖育成豚 (以下育成豚) および繁殖母豚（以下母豚）の脚弱につい て調べた。 


\section{材料および方法}

1. 調查期間：2002年 10 月から 2003年 3 月。

2. 対象農場：千葉県内で常時母豚を40頭から 197 頭飼 育する養豚場11戸。

3 。供試豚：この11戸について，1 万あたり4頭〜22頭 の育成豚あるいは母豚を無作為に選拢し，合計で育成豚 94頭，母豚135頭を供試豚とした。

4. 調査項目：母豚と育成豚の肢蹄状沉・起立状態・駐 立状態，母豚のボディコンディションスコア（以下 BCS）・関節炎の有無，および豚舎環境を調查した。

母豚と育成豚の肢蹄状況は, Jørgensen $ら^{55}$, 古郡 31 楠 原 ", Grindflekら"およびVan Steenberg"11)による肢蹄異常 スコアリングシステムに関する報告にもとづいて，脚弱 の症状として以下の項目を観察した。

前肢の肢蹄状況（汹 1 ）では, 前膝前屈（四 2), 直肢
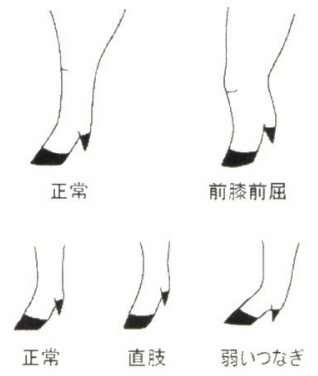

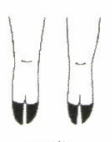

正常

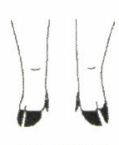

外向きの足

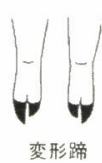

変形蹄
図 1 前肢の肢蹄状況の観察項日 (Jørgensen and Nørskov 原四)

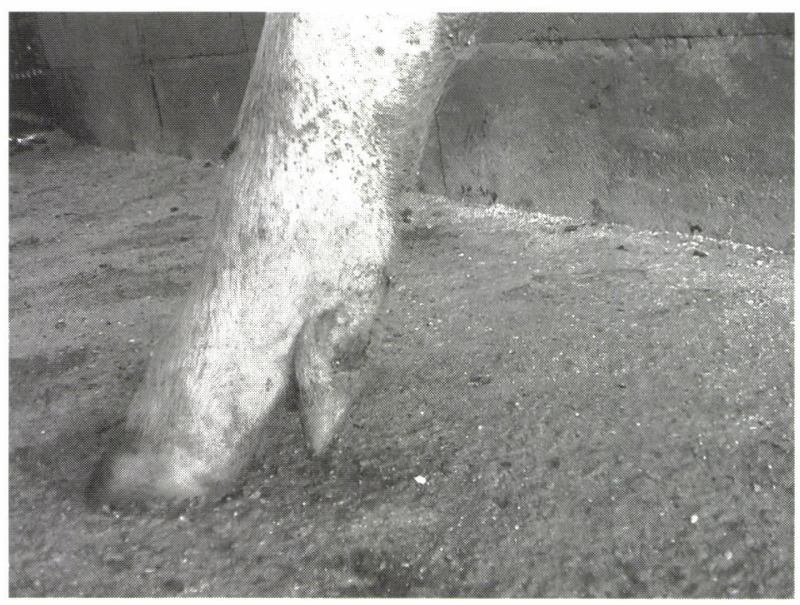

㲸 3 前肢の直肢
(図 3 ), 弱いつなき（四 4), 外向きの足 (四 5 ), 変形 蹄 (左右不揃い, 過長蹄) (図 6 ), 蹄の損傷（図 4 ）の 有無の 6 項目を，後肢の肢蹄状況（図 7 ）では, 湾曲 (図 8), 直肢（図 9), 弱いつなき（図10), 外向きの足 (四11), 変形蹄（図12）, 蹄の損傷の有無の6 項目を調べ た。育成豚の歩行状況は実際に豚舍を歩かせてみてこわ ばった歩行，後躯のゆ机（歩行時に後躯を左右に大きく 摇らして歩く，いわゆるモンローウォーク）を観察して, こわばった歩行はなし（－）あり（+）の2段階，また 後身のゆれはなし $(-)$, 軽度 $(+)$, 著しい $(++)$ の 3 段階で評価した。母豚と育成豚の起立状態（立ち上が る動作）は豚を起立させて, 普通・起立やや難・起立難 の 3 段階で評価した。駐立状態（立っている状態）は起 立している豚を観察し, 安定・不安定の 2 段階で評価し た。なおこれらの評価は担当獸医師（1 人）の判断で行 つた。

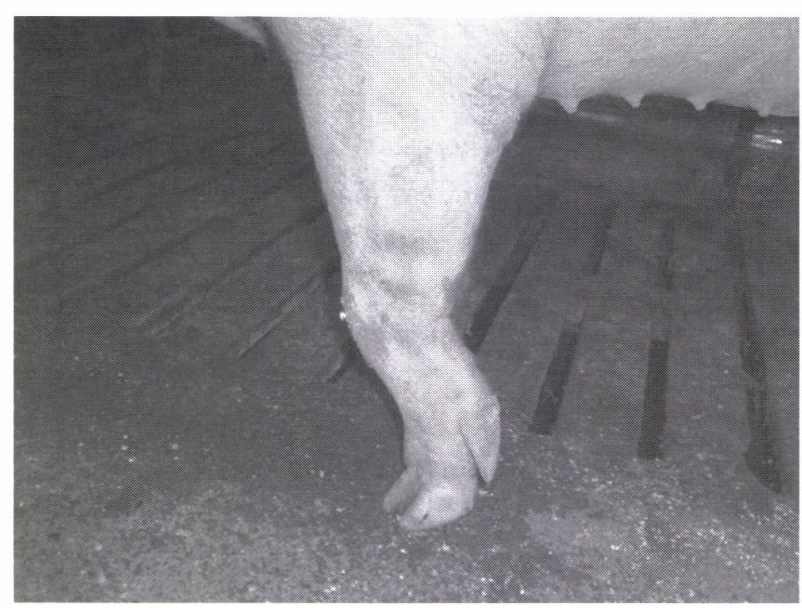

図 2 前膝前屈

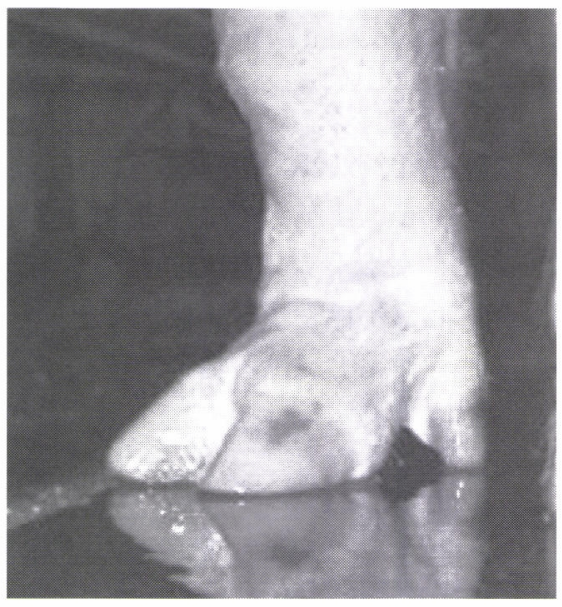

図 4 前肢の弱いつなぎおよび踹の損傷 


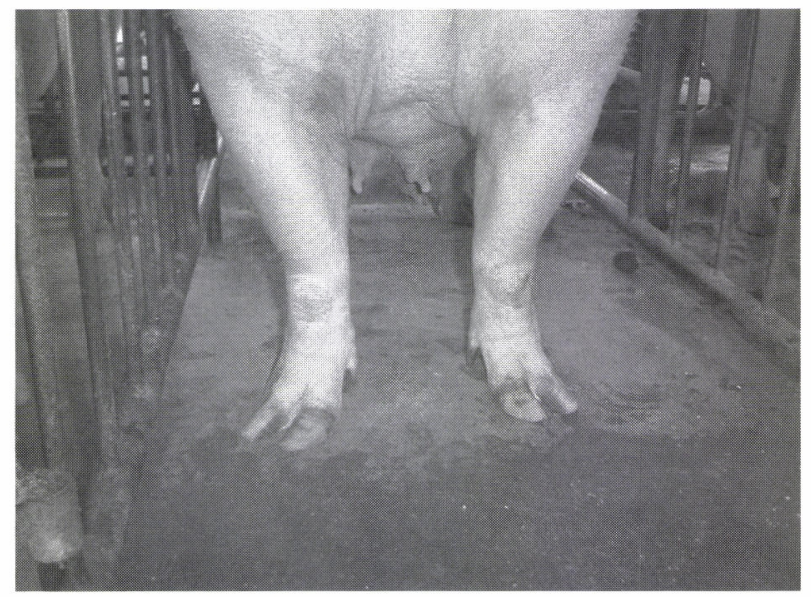

汹 5 前肢の外向きの足

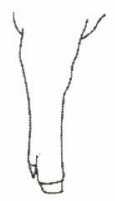

直肢
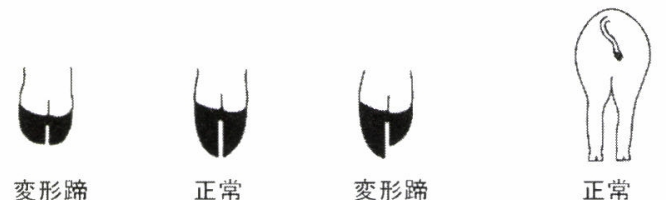

正常

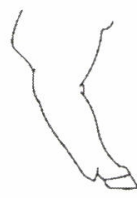

湾曲

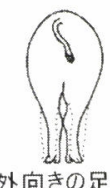

四 7 後肢の肢蹄状況の観察項目 (CCSI およびJørgensen 原図)

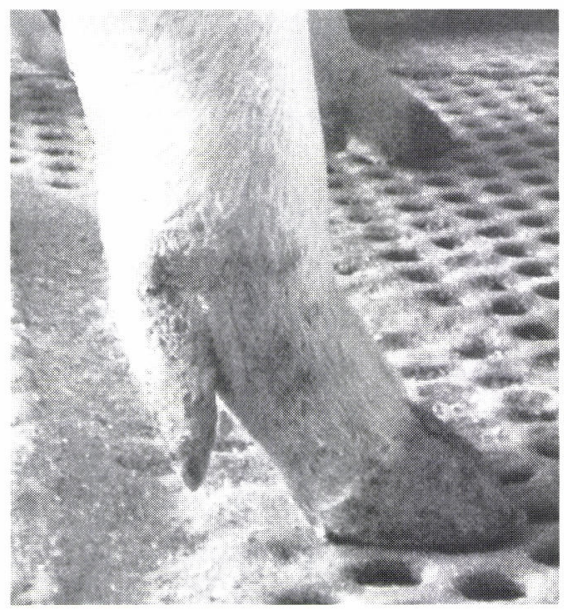

図 9 後肢の直肢

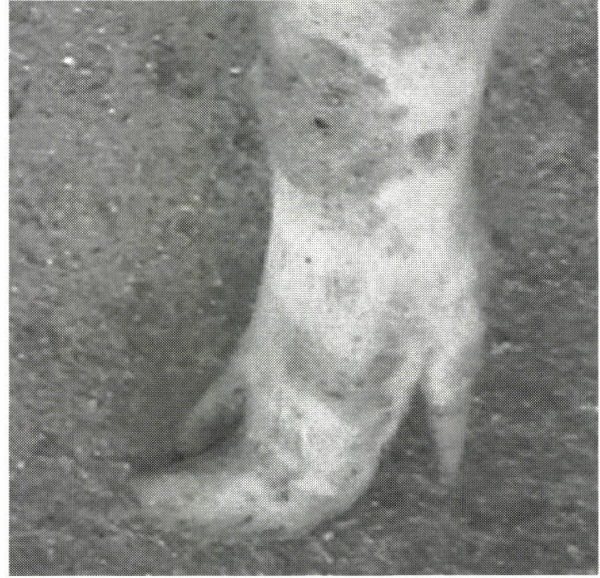

汹 6 前肢の変形蹄（この例は内外蹄の不揃い）

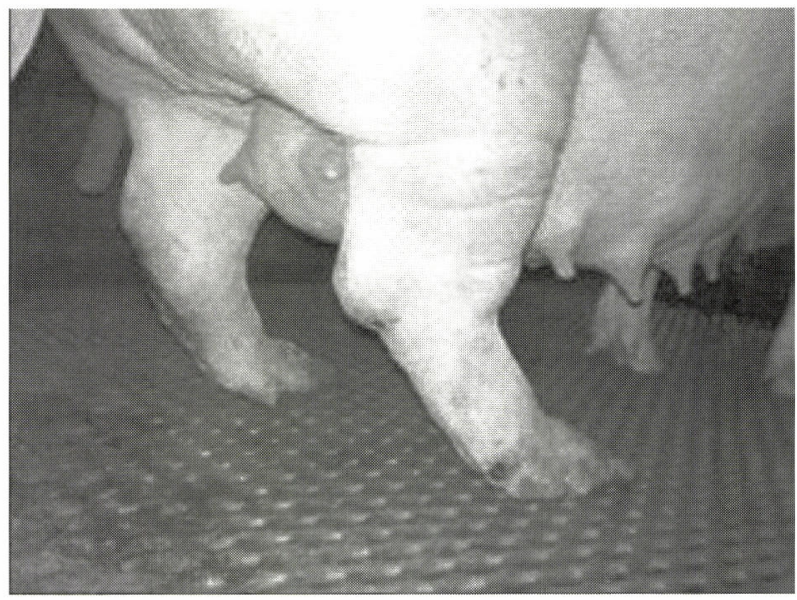

汹 8 後肢の湾曲

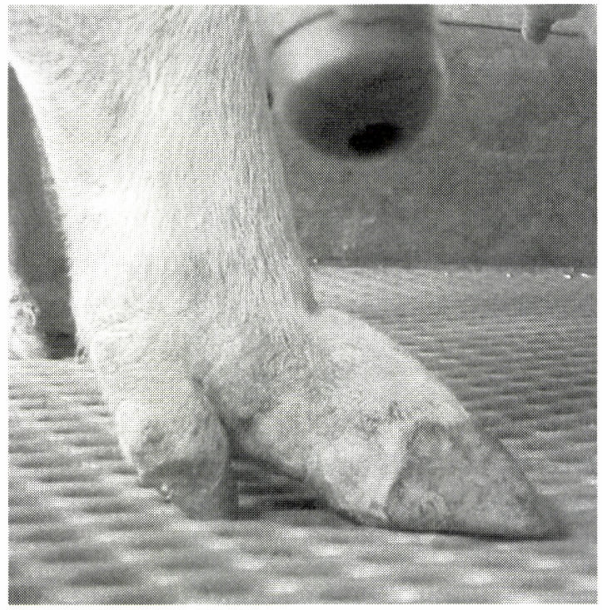

図 10 後肢の弱いつなぎ 


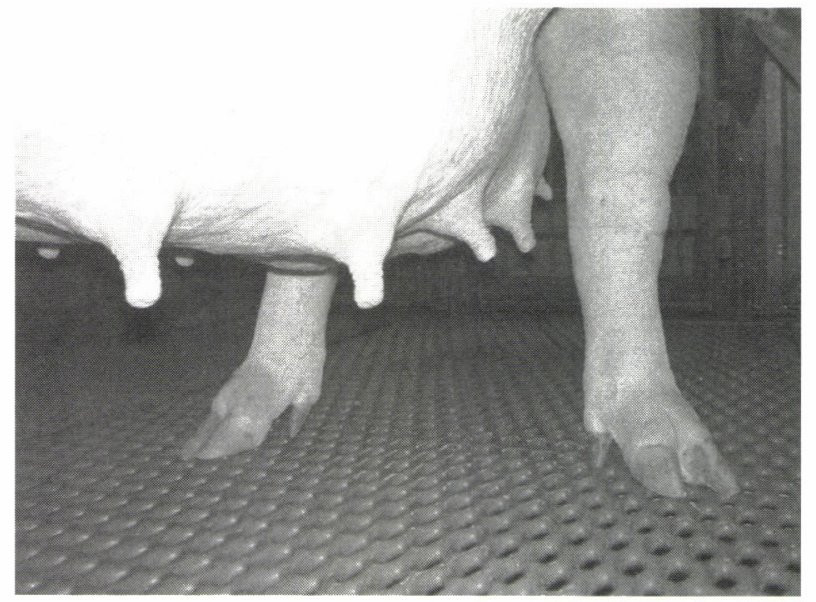

汹 11 後肢の外向きの足

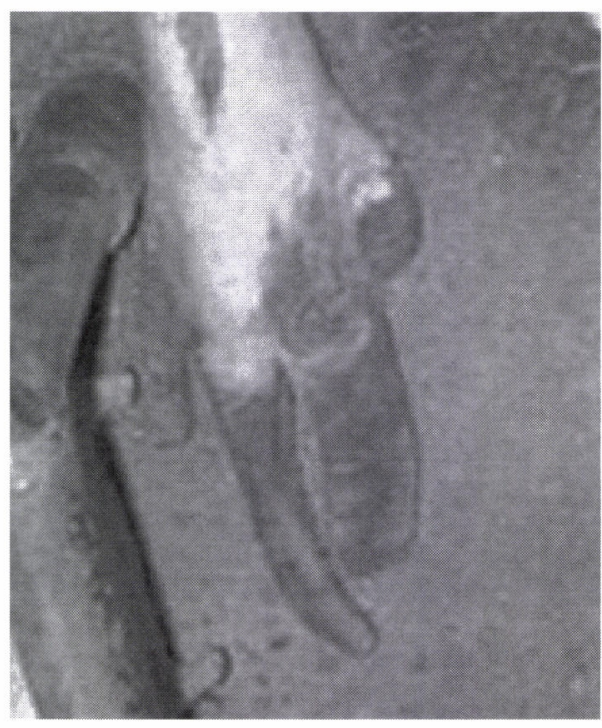

刅 12 後肢の変形蹄（この例は過長蹄）

表 1 繁殖育成豚および繁殖母豚の肢蹄状況

\begin{tabular}{|c|c|c|c|c|}
\hline \multirow{2}{*}{ 項目 } & \multicolumn{2}{|c|}{ 育成豚 } & \multicolumn{2}{|c|}{ 母豚 } \\
\hline & 前肢 & 後肢 & 前肢 & 後肢 \\
\hline 全膝前屈 & 1/94 (1.1) & - & $3 / 135 \quad(2.2)$ & - \\
\hline 湾曲 & - & 1/94 (1.1) & - & $7 / 135 \quad(5.2)$ \\
\hline 直肢 & $9 / 94 \quad(9.6)$ & $13 / 9 \quad(13.8)$ & $13 / 135 \quad(9.6)$ & $10 / 135$ \\
\hline 弱いつなぎ & $5 / 94 \quad(5.3)$ & 8/94（8.5） & $38 / 135 \quad(28.1)$ & $63 / 135 \quad(46.7)$ \\
\hline 外向きの足 & $8 / 94 \quad(8.5)$ & $13 / 94 \quad(13.8)$ & $14 / 135(10.4)$ & $58 / 135(43.0)$ \\
\hline 変形蹄 & $5 / 94 \quad(5.3)$ & $3 / 94 \quad(3.2)$ & $12 / 135 \quad(8.9)$ & $31 / 135 \quad(23.1)$ \\
\hline 蹄損傷 & $1 / 94$ & 1/94 (1.1) & $5 / 135 \quad(3.7)$ & $5 / 135 \quad(3.7)$ \\
\hline
\end{tabular}

各項且の陽性頭数/全頭数 $(\%)$

- : 該当無し

豚舍環境は豚房サイズ，床材の材質，敷料の有無，豚 房の污れ具合を調べた。豚房の污れ具合は, 担当獣医師 の判断で, 清潔・やや不潔・不潔の 3 段階で評価した。 また育成豚房の運動場の有無を調查した。

さらに，繁殖母豚の BCS別にみた弱いつなぎ，起立状 態および関節炎については，それぞれについて，BCS間 でカイ二乗検定を行った。

\section{成 績}

\section{1. 育成豚拧よび母豚の肢蹄状況}

育成豚の肢蹄状況は, 前肢では直肢が, 後肢では直肢 と外向きの足が多かった。母豚の肢蹄状況は，前肢では 弱いつなぎが, 後肢では弱いつなぎ外向きの足が多か った（表1）
母豚で最も多かった弱いつなぎについて育成豚と母豚 での発現率を農場別に比較した（表 2 )。育成豚では，す でに前肢，後肢ともに発現の多い農場（農場№. 1， 11） と，まったく発現していない農場（農場№.4，5，7） があったが, 母豚ではすべての農場で後肢に弱いつなぎ の豚が観察された。

また，母豚で多かった外向きの足を育成豚と比較し， 農場別に示した（表 3 ）。育成豚では発現の多い農場（農 場№. $1,2,8,10$ ) と, 全く発現しない農場（農場№. $7 ， 11 ）$ があったが，母豚では，ほとんどの農場で後肢 に外向きの足が多くみられた。特に農場 9 では $89.5 \%$ の 母豚が後肢に外向きの足を発現していた。

2. 育成豚抢よび母豚の起立状態扮よび駅立状態

農場別にみた育成豚および母豚の起立状態を表 4 に示 
表 2 農場別にみた繁殖育成豚および繁殖母豚の弱いつなぎの発現状況

\begin{tabular}{|c|c|c|c|c|}
\hline \multirow{2}{*}{ 農場NNo. } & \multicolumn{2}{|c|}{ 育成豚 } & \multicolumn{2}{|c|}{ 母豚 } \\
\hline & 前肢 & 後肢 & 前肢 & 後肢 \\
\hline 1 & $2 / 8 \quad(25.0)$ & $3 / 8 \quad(37.5)$ & $3 / 10 \quad(30.0)$ & $8 / 10 \quad(80.0)$ \\
\hline 2 & $2 / 10 \quad(20.0)$ & $0 / 10 \quad(0)$ & $4 / 7 \quad(57.1)$ & $5 / 7 \quad(53.8)$ \\
\hline 3 & $0 / 6 \quad(0)$ & $1 / 6 \quad(16.7)$ & 2/13 (15.4) & $7 / 13 \quad(53.8)$ \\
\hline 4 & $0 / 21 \quad(0)$ & $0 / 21 \quad(0)$ & $0 / 4 \quad(0)$ & $1 / 4 \quad(25.0)$ \\
\hline 5 & $0 / 8 \quad(0)$ & $0 / 8 \quad(0)$ & $0 / 22(0)$ & $4 / 22 \quad(18.8)$ \\
\hline 6 & $0 / 10 \quad(0)$ & $1 / 10 \quad(10.0)$ & $1 / 7 \quad(14.3)$ & $2 / 7 \quad(28.6)$ \\
\hline 7 & $0 / 4 \quad(0)$ & $0 / 4 \quad(0)$ & 7/9 (77.7) & $8 / 9 \quad(88.8)$ \\
\hline 8 & $0 / 12(0)$ & $1 / 12$ & $5 / 13 \quad(38.5)$ & 7/13 (53.8) \\
\hline 9 & - & - & 6/17 (35.3) & $7 / 17 \quad(41.2)$ \\
\hline 10 & $0 / 10 \quad(0)$ & $0 / 10 \quad(0)$ & 5/17 (29.4) & $8 / 17 \quad(47.1)$ \\
\hline 11 & $1 / 5 \quad(20.0)$ & $2 / 5 \quad(40.0)$ & $2 / 7 \quad(28.6)$ & $4 / 7 \quad(57.1)$ \\
\hline 全体 & $5 / 94 \quad(5.3)$ & 8/94（8.5） & $35 / 126 \quad(29.7)$ & $61 / 126 \quad(49.9)$ \\
\hline
\end{tabular}

各項目の陽性頭数/全頭数 （\%)

- : 観察せず

表 3 農場別にみた繁殖育成豚および繁殖母豚の外向きの足の発現状況

\begin{tabular}{|c|c|c|c|c|}
\hline \multirow{2}{*}{ 農場NNo. } & \multicolumn{2}{|c|}{ 育成豚 } & \multicolumn{2}{|c|}{ 母豚 } \\
\hline & 前肢 & 後肢 & 前肢 & 後肢 \\
\hline 1 & $1 / 8(12.5)$ & $5 / 8 \quad(62.5)$ & $2 / 10 \quad(20.0)$ & $6 / 10 \quad(60.0)$ \\
\hline 2 & $0 / 10 \quad(0)$ & $3 / 10 \quad(30.0)$ & $0 / 10 \quad(0)$ & $5 / 8 \quad(62.5)$ \\
\hline 3 & 1/8（16.7） & $0 / 8 \quad(0)$ & 4/15 (26.7) & $0 / 15 \quad(0)$ \\
\hline 4 & $0 / 21 \quad(0)$ & $3 / 8 \quad(14.3)$ & $0 / 4 \quad(0)$ & $2 / 4 \quad(50.0)$ \\
\hline 5 & $0 / 8 \quad(0)$ & $1 / 8 \quad(12.5)$ & $0 / 22(0)$ & $9 / 22(40.9)$ \\
\hline 6 & $0 / 10 \quad(0)$ & $1 / 10(10.0)$ & $0 / 7 \quad(0)$ & 4/7 (57.1) \\
\hline 7 & $0 / 4 \quad(0)$ & $0 / 4 \quad(0)$ & $0 / 11 \quad(0)$ & 4/11 (36.4) \\
\hline 8 & $3 / 8 \quad(25.0)$ & $0 / 12(0)$ & $0 / 13 \quad(0)$ & $3 / 13 \quad(23.1)$ \\
\hline 9 & - & - & $6 / 19 \quad(31.6)$ & $17 / 19 \quad(89.5)$ \\
\hline 10 & $3 / 8 \quad(30.0)$ & $0 / 10 \quad(0)$ & $1 / 18 \quad(5.6)$ & $5 / 18 \quad(27.8)$ \\
\hline 11 & 0/5（0) & 0/5（0) & $1 / 8 \quad(12.5)$ & $3 / 8 \quad(37.5)$ \\
\hline 全体 & 8/94 (8.5) & 13/94（13.8） & $14 / 135 \quad(10.4)$ & 58/135（43.0) \\
\hline
\end{tabular}

各項目の陽性頭数/全頭数 （\%)

- : 観察せず

した。全体では育成豚の $96.7 \%$ \%゙普通の起立状態であっ た。母豚では79.3\%が普通の起立状態だったが，起立や や難や起立難もそれぞれ $17.2 \% ， 3.4 \%$ 観察された。農場 別では，農場 9 の母豚で起立やや難が $31.6 \%$ ，農場 1 の母 豚で起立難が $25.0 \%$ 観察された。

また，農場別にみた育成豚および母豚の駐立状態を表 5 に示した。全体では，育成豚の $98.9 \%$ が安定していた。
母豚では $85.0 \%$ は安定していたが不安定なものも $15.0 \%$ 観察された。農場 9 の母豚では不安定なものが $31.6 \%$ 観 察された。

3. 育成豚の異常歩様の発現率

育成豚で歩行のこわばりが観察されたのは $18.3 \%$ (17/93)，後躯のゆれは+が38.7\% (36/93), ++は 3.2\%（3/93）だった。また，後躯のゆれが観察された39 
表 4 農場別にみた繁殖育成豚および繁殖母豚の起立状態

\begin{tabular}{|c|c|c|c|c|c|c|}
\hline \multirow{2}{*}{ 農場№。 } & \multicolumn{3}{|c|}{ 育成豚の起立状態 } & \multicolumn{3}{|c|}{ 母豚の起立状態 } \\
\hline & 普通 & やや難 & 難 & 普通 & やや難 & 難 \\
\hline 1 & $1 / 1 \quad(100)$ & $0 / 1 \quad(0)$ & $0 / 1(0)$ & $2 / 4 \quad(50.0)$ & $1 / 4 \quad(25.0)$ & $1 / 4(25.0)$ \\
\hline 2 & 10/10 (100) & $0 / 10 \quad(0)$ & $0 / 10 \quad(0)$ & - & - & - \\
\hline 3 & $1 / 2(50.0)$ & $1 / 2(50.0)$ & $0 / 2(0)$ & $9 / 10 \quad(90.0)$ & $1 / 10(90.0)$ & $0 / 10(0)$ \\
\hline 4 & $14 / 14(100)$ & $0 / 14 \quad(0)$ & $0 / 14 \quad(0)$ & $4 / 4 \quad(100)$ & $0 / 4(0)$ & $0 / 4(0)$ \\
\hline 5 & $8 / 8(100)$ & $0 / 8 \quad(0)$ & $0 / 8(0)$ & $16 / 22$ & $4 / 22(18.2)$ & $2 / 22 \quad(9.1)$ \\
\hline 6 & $10 / 10$ & $0 / 10(0)$ & $0 / 10 \quad(0)$ & $5 / 7 \quad(71.4)$ & $2 / 7 \quad(28.6)$ & $0 / 7 \quad(0)$ \\
\hline 7 & $4 / 4 \quad(100)$ & $0 / 4(0)$ & $0 / 4(0)$ & $10 / 11 \quad(90.9)$ & $1 / 11$ & $0 / 11 \quad(0)$ \\
\hline 8 & $11 / 12$ & $1 / 12$ & $0 / 12(0)$ & $8 / 13$ & $4 / 13 \quad(30.8)$ & $1 / 13$ \\
\hline 9 & - & - & - & $13 / 19(68.4)$ & $6 / 19$ & $0 / 19(0)$ \\
\hline 10 & - & - & - & $18 / 18(100)$ & $0 / 18 \quad(0)$ & $0 / 18 \quad(0)$ \\
\hline 11 & - & - & - & $7 / 8 \quad(87.5)$ & $1 / 8 \quad(12.5)$ & $0 / 18 \quad(0)$ \\
\hline 全体 & $59 / 61 \quad(96.7)$ & $2 / 61 \quad(3.3)$ & $0 / 61 \quad(0)$ & $92 / 116(79.3)$ & $20 / 116(17.2)$ & $4 / 116 \quad(3.4)$ \\
\hline
\end{tabular}

各項目の陽性頭数/全頭数 $(\%)$

- : 観察せず

表 5 農場別にみた繁殖育成豚および繁殖母豚の駐立状態

\begin{tabular}{|c|c|c|c|c|}
\hline \multirow{2}{*}{ 農場№。 } & \multicolumn{2}{|c|}{ 育成豚 } & \multicolumn{2}{|c|}{ 母豚 } \\
\hline & 安定 & 不安定 & 安定 & 不安定 \\
\hline 1 & $7 / 8 \quad(87.5)$ & $1 / 8 \quad(12.5)$ & $9 / 10 \quad(90.0)$ & $1 / 10 \quad(10.0)$ \\
\hline 2 & $10 / 10 \quad(100)$ & $0 / 10 \quad(0)$ & - & - \\
\hline 3 & $6 / 6 \quad(100)$ & $0 / 6 \quad(0)$ & $11 / 15 \quad(73.3)$ & $4 / 15 \quad(26.7)$ \\
\hline 4 & $14 / 14(100)$ & $0 / 14 \quad(0)$ & 4/4（100） & $0 / 4 \quad(0)$ \\
\hline 5 & $8 / 8 \quad(100)$ & $0 / 8 \quad(0)$ & $19 / 22 \quad(86.4)$ & $3 / 22(13.6)$ \\
\hline 6 & $10 / 10 \quad(100)$ & $0 / 10 \quad(0)$ & $5 / 7 \quad(71.4)$ & $2 / 7 \quad(28.6)$ \\
\hline 7 & 4/4 (100) & $0 / 4 \quad(0)$ & $11 / 11 \quad(100)$ & $0 / 11 \quad(0)$ \\
\hline 8 & $12 / 12(100)$ & $0 / 12(0)$ & $10 / 13(76.9)$ & $3 / 13 \quad(23.1)$ \\
\hline 9 & - & - & $13 / 19 \quad(68.4)$ & $6 / 19 \quad(31.6)$ \\
\hline 10 & $10 / 10 \quad(100)$ & $0 / 10 \quad(0)$ & $18 / 18 \quad(100)$ & $0 / 18 \quad(0)$ \\
\hline 11 & $5 / 5 \quad(100)$ & $0 / 5 \quad(0)$ & $8 / 8 \quad(100)$ & $0 / 8 \quad(0)$ \\
\hline 全体 & $86 / 87 \quad(98.9)$ & 1/87 (1.1) & $108 / 127(85.0)$ & $19 / 127(15.0)$ \\
\hline
\end{tabular}

頭のうち，外向きの足が認められた育成豚は $23.1 \%$ (9/39), 一方, 後躯のゆれがなかった 57 頭のうち外向き の足が認められた育成豚は $5.3 \%$ （3/57）だった。

4.母豚のBCSおよび関節炎

母豚の前肢および後肢の弱いつなぎ，起立状態掞よび 関節炎についてBCS別にみた（表 6 ）。母豚のBCSは2.0,
2.5，3.0，3.5および4.0が，それぞれ $6.7 \%$ (9/134)， $23.1 \%(31 / 134), 44.7 \%(60 / 134), 22.3 \%$ (30/134) 打 よび $3.0 \%$ (4/134) だった。

前肢の弱いつなぎは BCS 2.5 の豚が BCS 2.0 の豚より多 く認められた $(\mathrm{p}<0.05)$ 。起立状態やや難はBCS 2.5 の豚が BCS3.5の豚よりも多かった。また，関節炎は $18.8 \%$ の 
表 6 繁殖母豚の B C S 別にみた弱いつなぎ，起立状態および関節炎の状況

\begin{tabular}{|c|c|c|c|c|c|}
\hline \multirow{2}{*}{ BCS } & \multicolumn{2}{|c|}{ 弱いつなぎ } & \multicolumn{2}{|c|}{ 起立状態 } & \multirow{2}{*}{ 関節炎 } \\
\hline & 前肢 & 後肢 & やや難 & 難 & \\
\hline 2.0 & $4 / 9(44.4)$ & $5 / 8 \quad(66.7)$ & $1 / 9(11.1)$ & $1 / 9(11.1)$ & $2 / 5(40.0) \mathrm{e}$ \\
\hline 2.5 & $13 / 31(41.9)^{\mathrm{a}}$ & $18 / 31 \quad(58.1)$ & $7 / 30(23.3)^{\mathrm{c}}$ & $0 / 30 \quad(0)$ & $3 / 15(20.0) \mathrm{g}$ \\
\hline 3.0 & $11 / 60(18.3)^{b}$ & $26 / 60 \quad(43.3)$ & $10 / 59(16.9)$ & $2 / 59 \quad(3.4)$ & $0 / 21(0)^{\mathrm{f}}$ \\
\hline 3.5 & $9 / 30 \quad(30.0)$ & $13 / 30 \quad(43.3)$ & $1 / 30(3.3)^{d}$ & $1 / 30$ & $1 / 12$ \\
\hline 4.0 & $1 / 4(25.0)$ & $1 / 4 \quad(25.0)$ & $0 / 4 \quad(0)$ & $0 / 4(0)$ & $0 / 4(0)$ \\
\hline 全体 & $38 / 134 \quad(28.3)$ & $63 / 133(47.4)$ & $19 / 128(14.8)$ & $4 / 128(3.1)$ & 6/32 (18.8) \\
\hline
\end{tabular}

各項目の陽性頭数/全頭数 (\%)

a-b間， c-d間， e-f間およびg-f間で有意差あり $(\mathrm{p}<0.05)$

表 7 育成豚房の 1 頭当たりの床面積と運動場の有無

\begin{tabular}{cccc}
\hline 農場No. & 豚房タイプ1) & $\begin{array}{c}1 \text { 頭当たりの } \\
\text { 床面積 }\left(\mathrm{m}^{2}\right)\end{array}$ & 運動場の有無 \\
\hline 1 & - & 3.5 & - \\
2 & - & 2.6 & - \\
3 & - & 2.1 & + \\
4 & A & 2.2 & - \\
4 & B & 2.2 & - \\
4 & C & 2.8 & - \\
4 & D & 2.1 & - \\
5 & A & 3.0 & - \\
5 & B & 1.5 & - \\
5 & C & 3.2 & - \\
5 & D & 2.1 & - \\
6 & A & 3.9 & - \\
6 & B & 2.4 & - \\
7 & - & 1.7 & - \\
8 & A & 1.0 & + \\
8 & B & 1.2 & - \\
9 & - & 2.5 & + \\
10 & - & 3.3 & - \\
11 & A & 4.0 & - \\
11 & B & 3.8 & - \\
\hline
\end{tabular}

1） 1 農場に複数の型式の豚房がある場合, タイプごとに 測定した。

豚で認められた。BCS別の関節炎発症率は, BCS2.0や 2.5 の豚はBCS3.0の豚よりも高かった。

5 . 育成豚の 1 頭当たりの床面積と運動場

育成豚房の幅と長さを測定し，1頭当たりの床面積を
農場ごとにみた（表 7 ）。農場 7 と農場 8 は, 1 頭当たり の床面積が狭く, 農場 7 は 2 頭用の豚房に 5 頭収容され, 運動場もない豚房だった。また, 農場 8-Aは運動場のあ る豚房で，農場8-Bは育成豚用のストールであった。

\section{考 察}

今回の実態調査では，すべての農場において脚弱症状 を示す豚が多く観察され, 脚弱の豚はどのような農場で も発生する危険性があると考えられた。全国や千葉県に おける死廃率のうちの $30 \%$ 運動器疾患であることは, 今回脚弱が非常に多く観察されたことと関係があると思 われる。

肢蹄異常は育成豚，母豚ともに後肢に多く発現してい た。後肢は交配時に雄豚の体重がかかり，後肢が弱いと 股開きや犬座姿勢を発現しやすくなり，ストールから分 娩舎への移動時などにも歩行困難をきたすなどの影響が 考えられる。したがって繁殖育成豚の導入時には後肢の 強さも考慮する必要がある。

育成豚で多く見られた值肢は, 歩様が硬く, 関節の屈 曲角が正常のものよりも大きいということが証明されて いる ${ }^{3)}$ 。屈曲角が大きいと体重の負重や物理的衝撃に対 する関節の吸収力が低下し，結果として骨軟骨症を発現 させることになる ${ }^{31}$ 。育成豚の段階から直肢が多く観察 されたことは, 早くから起立や歩行に支障をきたし, 将 来的には淘汰対象になる可能性があると考えられる。ま た育成豚では後躯のゆれが見られたものに外向きの足を 発現しているものが見られた。外向きの足は, 後ろから の外見上は腿張りがよく見えるが，その歩行はいわゆる 外弧歩様となり, 蹄や関節への体重のかかり具合が不均 一になりうると考えられる。また，後肢がすべりやすく 起立も困難になりやすいと考えられる。母豚で多かった 弱いつなぎは，つなぎ周囲（特に後肢）の筋肉, 勒帯の 
弱さも示しているものと考えられる。

弱いつなぎや外向きの足は農場によって発現の仕方に 違いがみられ, 農場 1 や農場 10 のように育成豚も母豚も 弱いつなぎや外向きの足が多い農場や，農場 7 や農場 8 のように育成豚は良好なのに母豚になると弱いつなぎや 外向きの足を発現する農場などがあった。これは，畜主 の育成豚に対する選抜基準，たとえば産肉性重視か強健 性重視かの違いや育成豚の段階での飼育環境などの違い によると思われる。

農場 7 は育成豚の時点では弱いつなぎのものはみられ ないが，母豚になると弱いつなぎが多く観察された。こ の農場の育成豚は敷料のない育成豚房に密飼いされ（2 頭用の豚房に 5 頭収容），運動場もなく運動制限を強いら れた状態であった。さらにこの育成豚房に 20 日間だけ収 容され，発情が来ればすぐに育成豚房よりさらに狭いス トールに移されていた。そのため, 関節に体重の負担が 少ない育成豚の時点では異常はなく, 増体が進むにつれ て脚弱症状を発現したものと思われる。農場 1 は起立難 の豚が最も多く観察されたが，この農場のストールの床 はコンクリート製で表面は鏡面状であり，起立時に非常 に滑りやすかった。このすべりやすい床は母豚の起立難 と弱いつなぎの発現を助長していると考えられた。

またBCSが低く瘦せている母豚はBCS 3.0 の母豚よりも 関節炎や起立難が多く観察される傾向にあったが，これ らはもともと肢蹄に異常があり，そのために起立を嫌悪 して採食量や飲水量が低下した結果BCSが低下したもの と考えられる。よって，BCSの低下を防ぐために給飭時 間にもかかわらず起立しない豚は，早期発見するととも に敷料を十分に入れた広い豚房に移動させることが必要 と思われた。

以上のように脚弱の豚は多くの農場で認められ，これ が運動器病の多さにつながっているものと考えられた。 そこで, 脚弱の豚を導入しないように選抜時には四肢や 歩行の状態に注意することや，もし脚弱の危険性のある 育成豚を導入してしまった場合は,急激な増体による関節 への負担にならないよう過度の給飭を避け，十分な敷料 を入れて滑らないようにしたり, 広い豚房で飼育するな どして脚弱の発現を予防する必要があると思われた。

\section{要 約}

2002 年 10 月から 2003 年 3 月に千葉県内養豚家 11 戸の 繁殖育成豚 94 頭, 繁殖母豚 135 頭を対象に前・後肢の肢
蹄状況，歩行状況，起立状態抢よび駐立状態について調 査した。育成豚の前肢は直肢 $(9.6 \%)$, 後肢は直肢 (13.8\%) および外向きの足（13.8\%）が多く，母豚の前 肢は弱いつなぎ $(28.1 \%)$, 後肢は弱いつなぎ $(46.7 \%)$ と外向きの足 $(43.0 \%)$ が多かった。母豚で起立状態や や難が $17.2 \%$ ，起立難が $3.4 \%$ ，駐立状態不安定が $15.0 \%$ だった。育成豚でこわばった歩行を呈したものが $18.3 \%$, 後躯のゆれを呈したのが $41.9 \%$ \%だった。CSが低い母豚 は関節炎，弱いつなぎ，起立難が多かった。どの農場に おいても脚弱の豚が多く観察され，特に後肢に異常が多 くみられた。

\section{引用文献}

1) 古郡浩：豚の脚弱一その原因，診断抢よび予防法 （上）.家畜診療，256，3-13， 1984.

2 ）古郡浩：豚の脚弱一その原因，診断および予防法 （中）.家畜診療，257，41-48，1984.

3 ）古郡浩：豚の脚弱一その原因, 診断および子防法 （下）.家畜診療，258，17-24， 1984.

4 ) Grindflek,E. and Schested,E.:Conformation and longevity in Norwegian pigs.Proceedings of NJFSeminar no. 265, 77-83, 1996

5 ) Jørgensen,B. and Vestergaard,T. : Genetics of leg weakness in boars at Danish pig breeding stations. Acta Agric. Scand., 40, 59-69, 1990.

6 ) Jørgensen,B. : Effect of different energy and protein levels on leg weakness and osteochondrosis in pigs.Live.Product.Sci., 41, 171-181, 1995.

7 ) Jørgensen,B.and Sorensen,M.T. : Different rearing intensities of gilts:2.Effects on subsequent leg weakness and longevity. Live.product.Sci., 54, 167171, 1998.

8 ) Jørgensen,B. : Osteochondrosis/Osteoarthrosis and claw disorders in sows,associated with leg weakness. Acta Vet.Scand., 41, 123-138, 2000.

9 ) 楠原征治：脚弱。柏崎守 編集, 豚病学第 4 版, 477-480，近代出版，東京， 1999.

10）農林水産省経営局：平成 13 年度家畜共済統計表, 農林水産省, 東京, 2003.

11) Van Steenbergen,E.J.:Description and evalution of a linear scoring system for exterior traits in pigs. Livest. Prod. Sci., 23, 163-181, 1989. 